\title{
A Social Accounting Matrix for India, 2005-06
}

\author{
Basanta K Pradhan $^{1}$, M.R Saluja ${ }^{2}$ \& Yashobanta Parida ${ }^{3, *}$ \\ ${ }^{1}$ Institute of Economic Growth, Delhi University Enclave, Delhi-110007, India \\ ${ }^{2}$ India Development Foundation, Gurgaon-122002, Haryana, India \\ ${ }^{3}$ Institute of Economic Growth, Delhi University Enclave, Delhi- 110007, India \\ *Corresponding author: Institute of Economic Growth, Delhi University Enclave, Delhi- \\ 110007, India. Tel: 91-11-2766-6364 ext-231. E-mail: yashparida@gmail.com
}

Received: November 10, 2013 Accepted: December 15, 2013 Published: February 13, 2014

doi:10.5296/rae.v6i1.4528ＵRL: http://dx.doi.org/10.5296/rae.v6i1.4528

\begin{abstract}
This paper aims to construct a Social Accounting Matrix (SAM) for India and explain the methodology in the process. This SAM consists of 41 sectors of the economy, two factors of production, nine occupational categories and ten expenditure categories of households. The SAM has been constructed for the Indian economy for 2005-06. The distribution of income is based on data for 2004-05. The electricity sector has been decomposed into three sectors column-wise, namely hydro, nuclear and thermal. Besides the subdivision of electricity sector, the other energy sector has also been divided into coal and lignite, crude oil and natural gas, and petroleum products, which will be useful for energy modeling. The expenditure wise division of households will help in modeling inclusive growth issues.
\end{abstract}

Keywords: SAM; household categories; energy Sectors; India

JEL Classification: R15; R21; Q41 


\section{Introduction}

This paper describes the construction of the SAM for the Indian economy for 2005-06. A SAM is a square matrix, which can be interpreted as a complete description of the entire market plus some non-market transactions of commodities and primary factors of production within an economy and with outside agents. It consists of row-and-column accounts that represent different production activities, economic agents, institutions, and policy instruments in an economy. A SAM is based on the principle of balance between expenses (shown in columns) and receipts (shown in rows) for each sector of the economy. In practice, a SAM is the natural extension of Leontief's input-output (I-O) accounting system, and includes not only inter-industry transactions but also payments to factors of production, expenditures by households, transfers and subsidy expenditures of government, and transactions with the rest of the world. Building a SAM requires compiling different types of statistical data from multiple sources and reconciling data from these sources. The SAMs are now widely used in economic modeling and, in particular, in Computable General Equilibrium (CGE) models.

The objective of our study is to construct a SAM for the Indian economy for the year 2005-06. To our knowledge there is no SAM constructed for India for the year 2005-06. In order to construct the SAM for 2005-06 we have used Input-Output (I-O) data for 2006-07. We have changed the I-O table backward from 2006-07 to 2005-06. Here, we have segregated the households by nine occupational categories (Appendix Table 1) and by ten expenditure categories (Appendix Table 2). One of the major purposes of our SAM is to separate electricity sectors into three different sub-sectors viz. hydro, nuclear and thermal. We did it only for column-wise as in India the supply of electricity does not distinguish among the sources of generation. However, one can do it, following others in the literature by assuming the proportion in use as same in the proportion in production. The other SAMs for India which have done this division (here both row-wise and column-wise) is Pal et al. (2012) and Ojha et al (2009). Pal et al (2012) also has Biomass as a separate sector. We have not separated biomass as well. Biomass consists of crop residuals, dung, firewood, paper residual and food and beverage residual. These are all very heterogeneous products. Except for firewood, all these are byproducts. We have therefore taken these products along with main sectors e.g. firewood with forestry and dung with animal husbandry.

We have used the distribution of income by occupation category from the income and expenditure survey conducted by the NCAER for 2004-05.The income distribution for all other recent SAMs for India are based on the Micro Impact of Macro and adjustment Policies in India (MIMAP) Survey conducted by the NCAER for 1994-95 (see Pradhan and Roy, 2003). The present SAM consists of 41 sectors of the economy with two factors of production and five categories of rural occupational households and four urban occupational households. Further, we have five rural and five urban expenditure classes. The groupings include crucial sections like the poor and the abject poor households in separate categories.

The remaining part of this paper is divided into five sections. The literature review is given in Section 2. Section 3 provides the methods of deriving the I-O table for 2005-06 from 2006-07 table. Section 4 describes extension of the 1-O for construction of SAM. Section 5 provides 
some analytical aspects of this SAM. The concluding remarks are in Section 6.

\section{Literature Review}

Researchers have constructed a number of SAMs for India over the years. To our knowledge, Sarkar and Subbarao (1981) have constructed the earliest SAM for India; it consists of three sectors, namely agriculture, industry and services, and the government as an institution. Income is divided into agricultural wage income, non-agricultural wage income and non-agricultural non-wage income. Similarly, the SAM constructed by Sarkar and Panda (1986) has six production sectors and the private income of the economy is divided into three occupation classes. The SAM by Bhide and Pohit (1993) consists of six production sectors; they have separated livestock and forestry and industry as a single entity in their SAM. The nature of income classification in these SAMs does not help in the analysis of the size distribution of income.

The SAM constructed by Pradhan et al. (1999) for the Indian economy for 1994-05 was more complete in many aspects than the earlier ones. This SAM has 60 production sectors and two factors of production, namely labour and capital; households are classified into 12 occupational categories - six each for rural and urban areas-and two institutions, private corporate, and public non-departmental enterprises. The personal income distributed among different household categories is based on the MIMAP Survey. Pradhan et al. (2006) has provided a SAM for the Indian economy for 2002-03 consisting of 45 sectors and nine occupational categories of households.

The SAM for 2003-04 by Saluja and Yadav (2006) consists of 73 producing sectors and three institutions including household sectors, which are divided into five rural and five urban expenditure classes. This SAM provides separate sectors for crude oil, natural gas and various petroleum products. The SAM constructed by Kumar and Parikh (1996) focuses on assessment of the impact of climate change on Indian agriculture. The SAM by Ravindranath et al (2006) assesses the impact of climate change on forests in India. The SAM by Parikh et al (2009) analyzes the total $\mathrm{CO}_{2}$ emissions of the Indian economy in 2003-04. The SAM by Ojha et al (2009) has decomposed the electricity sector into three separate sub-sectors, such as hydro, nuclear and non-hydro. The recent SAM for India for 2007-08 by Pradhan et al (2013) has focused on 78 sectors of the Indian economy. This SAM has attempted to disaggregate a few sectors which are more important for the analysis of inclusive growth.

A large number of multiplier based SAMs were constructed by many scholars for various countries. The early SAMs were constructed by Pyatt and Round (1979) for Sri Lanka economy, Defourny and Thorbecke (1984) for Korea, Powell and Round (2000) for Ghana, Hayden and Round (1982) for Botswana and Thorbecke, et al (1992) for Indonesia. All these studies have examined the nature of the multiplier effects of an exogenous change on the socio-economic groups of households. 


\section{Changing 2006-07 I-O Table to 2005-06 I-O Table}

In this section, we discuss the methodology of changing the I-O table from 2006-07 to 2005-06. The Central Statistical Organization (CSO) has prepared a 130-sector Commodity x Industry flow matrix (absorption matrix) for 2006-07. First, we have obtained the Commodity x Commodity (CxC) I-O table for the year 2006-07 by making use of this absorption matrix and the make matrix for the year 2003-04. Then changed this CxC I-O table of 2006-07 to I-O table of 2005-06. The 130-sector I-O table is aggregated to form 41 sectors and translated into 2005-06.It may be mentioned here that the coefficient matrix is derived from the CxC I-O tables for the year 2006-07. The sources, the methodology used, the assumptions made and the problems encountered for estimating the sector-wise value added, value of output and various components of final demand are discussed below by broad sectors of the economy.

As described for the 1994-95 SAM (see Pradhan et al., 1999), the methodology remains similar in this SAM of changing I-O table from 2006-07 to 2005-06 for different sectors: agriculture (sectors 1 to 4),manufacturing industries (sectors 12 to 28), animal husbandry (sector 5), forestry and fishery (sectors 6 and 7) and mining (sectors 8 to 11). Similarly, there is no change in the methodology for converting different components of final demand, such as private final consumption expenditure (PFCE), government final consumption expenditure (GFCE), and gross fixed capital formation (GFCF). The concordance map between our 41 sectors and 130 sectors of the I-O table and NSSO commodity classification are shown in Table 1. The methodology used to extend the I-O table to the SAM is detailed in Section 4.

Table 1. Aggregated 41 Sectors Classification of 2005-06 I-O Transaction Table

\begin{tabular}{|c|c|c|c|}
\hline \multicolumn{2}{|c|}{ Description of Sectors } & \multirow[t]{2}{*}{130 I-O Sectors } & \multirow{2}{*}{$\begin{array}{l}\text { NSSO Commodities } \\
101-106\end{array}$} \\
\hline S1 & Paddy & & \\
\hline S2 & $\begin{array}{l}\text { Wheat } \\
\text { Commercial }\end{array}$ & 2 & $107-114$ \\
\hline S3 & Corps & $8,9,10,11,12,13,17$ & $\begin{array}{l}\text { 259, } 329 \\
115,139,159,229,\end{array}$ \\
\hline S4 & $\begin{array}{l}\text { Other Crops } \\
\text { Animal }\end{array}$ & $3,4,5,6,7,14,15,16,18,19,20$ & $\begin{array}{l}\text { 249, } 289 \\
\text { 169, } 189 \text { excludes 181, }\end{array}$ \\
\hline S5 & $\begin{array}{l}\text { Husbandry } \\
\text { Forestry and }\end{array}$ & $21,22,23,24$ & 343 \\
\hline S6 & logging & 25 & 341 \\
\hline S7 & Fishing & 26 & 181 \\
\hline S8 & $\begin{array}{l}\text { Coal and lignite } \\
\text { Crude }\end{array}$ & 27 & 347,350 \\
\hline S9 & petroleum & 29 & \\
\hline S10 & Natural gas & 28 & 352 \\
\hline S11 & $\begin{array}{l}\text { Other Mining } \\
\text { Food and }\end{array}$ & $30,31,32,33,34,35,36,37$ & \\
\hline S12 & Beverage & $38,39,40,41,42,43,44,45$ & $179,269,279,309$ \\
\hline S13 & Textile and & $46,47,48,49,50,51,52,53,54,59,60$ & 379, 389, 399 excludes \\
\hline
\end{tabular}




\section{Macrothink}

Leather

S14 Wood Products 55,56

Petroleum

S15 products

Coal tar

S16 products

Chemical and

Rubber and

S17 Plastic Products

Paper and Paper

S18 Products 57,58

Fertilizer and

S19 pesticide

S20 Cement

Other

Non-Metal and

Mineral

S21 Products

64

$61,62,65,66,69,70,71,72,73$

67,68

75

76,74

$77,78,79$

Non-Ferrous

S23 Basic Metals

S24 Metal Products

Non-Electrical

S25 Machinery

Electrical

S26 Mercenary

Transport

S27 Equipment

Miscellaneous

S28 Manufacture

80

81,82

$83,84,85,86,87$

$88,89,90,91,92,93,94$

$95,96,97,98,99,100$

101,102,103,104,105

106

Part of 107

Part of 107

Part of 107

108

109

S32

S30A Thermal

S30B Nuclear

Land Transport

Including via

S33 Pipeline

501

502, 503, 512, 513

Research in Applied Economics

ISSN 1948-5433

2014, Vol. 6, No. 1

393

551-553, 557

508, 510, 511

340

346, 351, 459,467,

468, 470, 493,613, 465

400, 401, 403

472

463

579, 464, 444, 442,

580, 581, 597, 640

596

441, 460-462, 560-563,

609 excludes 596, 641

610, 611, 612, 614

440, 564-568, 582,

583,629, 639,

642, 643

Part of 342

Part of 342

Part of 342

540

504 


\begin{tabular}{llll}
\hline S35 & $\begin{array}{l}\text { Air Transport } \\
\text { Supporting and } \\
\text { aux. Transport }\end{array}$ & 112 & 500 \\
S36 & $\begin{array}{l}\text { Activities } \\
\text { Storage and }\end{array}$ & 113 & 505,506 \\
S37 & Warehousing & 114 & \\
S38 & $\begin{array}{l}\text { Other Service’s } \\
\text { Medical and }\end{array}$ & $115,116,117,118,119,120,123,124,125,126,127,128,129$ & 499 \\
S39 & $\begin{array}{l}\text { Health } \\
\text { Education and }\end{array}$ & 122 & 419,429 \\
S40 & $\begin{array}{l}\text { Research } \\
\text { Pub Admin }\end{array}$ & 121 & $402,403,404,405$, \\
S41 & 130 & 406 \\
\hline
\end{tabular}

\subsection{Division of Electricity Sector into Three Components (Thermal, Hydro and Nuclear)}

National thermal, hydro and nuclear power corporations give yearly income and item-wise expenditure data for the power they produce. Here, the total input, total output, total value added and total net indirect tax are distributed according to the shares of total income of thermal, hydro and nuclear electricity. The detailed input structures available from these corporations are used for the entire generation of the respective kind of electricity. It is assumed that the input-output structure available from the NTPC and the NHPC for the entire generation of thermal electricity and hydroelectricity, respectively. The value of generation of nuclear power is taken as such. Similarly the sector wise value added is obtained. The total of value added and total values of output obtained in this way are different from the corresponding values given in the SAM for the entire electricity sector. The values obtained are adjusted pro rata with the control totals given in the SAM. Similarly, for the inputs available directly from the reports of power corporations, the adjustments are made pro rata to get the inputs given in the SAM. For thermal power, the fuel expenditures are given in terms of coal, gas, naphtha and oil. The corresponding estimates as given in the SAM are assumed under thermal power. For hydro, there is no expenditure shown under fuel. Only power charges are shown, which are taken as electricity consumption. Sector-wise allocation of inputs other than fuel was done on the basis of the proportions obtained for the entire electricity sectors. For nuclear power, uranium and heavy water are shown under fuel. Uranium has been put under other minerals and heavy water under chemicals. As these inputs are not shown in the SAM (because these are not being there in the CxC table 2006-07 of the $\mathrm{CSO}$ ), the adjustment for heavy water is made against chemicals. The value of uranium, put under other minerals, has been subtracted from other services sector so as to keep the total expenditure same.

\subsection{Energy Sectors}

For this SAM, more emphasis is on the energy sectors; hence the following details are given. Energy sectors taken separately in the SAM are coal and lignite, natural gas, petroleum products and the three electricity sectors (thermal, hydro and nuclear electricity). Crude oil, 
although taken as a separate sector, is not taken under energy because it is an input into petroleum products, which are taken under the energy sector. There are other materials that contribute to energy but are not separately taken. The names of the materials along with the reasons for not taking them as separate sectors are given below.

First, biomass fuel such as fuel wood forms part of the forestry sector and its inputs are not separately available. Crop residue is a by-product of sectors under agriculture; it is not feasible to have them as separate sectors. Similarly, animal dung is a by-product of the animal husbandry sector. Second, in addition to the forms of power generation mentioned above, power is generated by renewable energy sources like solar and wind. We have not considered these forms of energy because in 2008-09, the quantum of power generated by these sources was only 0.8 per cent of the total quantum generated. However, its contribution in terms of installed capacity could increase later.

\subsection{Other Sectors (31 to 41)}

The input and output structures for other sectors are based on the I-O table for 2006-07.The value of output and value added are given in the National Accounts Statistics (NAS) 2009.The technical coefficients for year 2006-07 and output for year 2005-06 has been used for preparing input -output structure for year 2005-06.

\subsection{Final Demand}

\subsubsection{PFCE}

The PFCE data at item level for 2005-06 and 2006-07 are obtained from NAS. These items are mapped according to our SAM sectors, and the growth rates between 2005-06 and 2006-07 are calculated from these data. These growth rates are applied to deflate 2006-07 PFCE to get detailed sector-wise estimates for 2005-06. For a few sectors (i.e. petroleum, railways, air transport, and health).we could not calculate the growth rates. In such cases, the change in the value of output is assumed for the change in PFCE.

\subsubsection{GFCE}

The total GFCE is available from NAS. The total government expenditure on goods and services obtained from the NAS is divided into different sectors by making use of 2006-07 structure. However, for education and health, the change in output between the two years is used for getting GFCE for 2005-06.

\section{Extension of I-O for Construction of SAM}

In the previous section, we have described the change from 2006-07 I-O data to 2005-06 data for our SAM. In this section, we discuss the methodology and the data sources for estimation of 2005-06 SAM. First, the total value added is decomposed into wage and non-wage income. Second, the PFCE and personal incomes are divided into households according to their occupation. Third, the PFCE is divided into 10 different expenditure classes in expenditure SAM. Fourth, the methods of construction of other relevant accounts of the SAM are also 
discussed in this section. In both SAMs, we have followed the method for different sectors: agriculture, allied activities and mining (1 to7 and 11), construction (sector 29),transport, storage and warehousing and other services (sectors 31 to 41),taxes (direct and indirect) and capital account are the same as described for the 1994-95 SAM (see Pradhan et al, 1999).

\subsection{Manufacturing Industries (Sectors 12 to 28)}

The output of manufacturing industries comprises the outputs of the organized and the unorganized manufacturing sectors. For the organized manufacturing sector, the GVA is divided into wages and non-wages income on the basis of the Annual Survey of Industries (ASI). Similarly, in case of unorganized manufacturing sectors, the ratio of wages and non-wages income is based on the Operational Characteristics of Unorganized Manufacturing Enterprises in India, Report No 524 (CSO, 2005).

\subsection{Distribution of Sector-Wise Consumption Expenditure by Occupational Categories of} Households

The sector-wise PFCE data is obtained from the I-O table for the year 2006-07. The NSSO $61^{\text {st }}$ Round gives the expenditure for different occupational classes for five rural and four urban categories (Table 2). To estimate consumption expenditure as per our SAM sectors, we have prepared a concordance between 41 SAM sectors and the NSSO's items (Table 1). The ratios of expenditure of different categories of household to total expenditure for different sectors are used to distribute the total sector-wise PFCE into different occupational categories in our SAM. The total of indirect taxes on PFCE is divided into taxes paid by different household categories in proportion to the total expenditures of these categories on non-agricultural commodities. The sum of total expenditure on different sectors and indirect taxes paid by different category of households are equal to the total expenditure for each category.

Table 2. Household Categories Used in the Construction of SAM

\begin{tabular}{llll}
\hline & \multicolumn{1}{c}{ Rural } & \multicolumn{1}{c}{ Urban } \\
\hline RH1 & Non-agricultural Self Employed & UH1 & Self Employed \\
RH2 & Agricultural Labour & UH2 & Salaried Class \\
RH3 & Non-agricultural Labour & UH3 & Casual labour \\
RH4 & Agricultural Self Employed & UH4 & Other households \\
RH5 & Other households & & \\
\hline
\end{tabular}

4.3 Distribution of Sector-Wise Consumption Expenditure by Expenditure Classes of Households

The NSSO $61^{\text {st }}$ Round of consumer expenditure survey gives the consumption expenditure by 12 classes of rural and urban categories. We have clubbed these classes into five rural and five urban expenditure classes based on 2003-04 SAM by Saluja and Yadav (2006) (see Table 3). Using the expenditure data, the relative expenditure of each expenditure class is obtained. For a few sectors (such as oil seeds, trade, banking and insurance, business services, and real estate activities) the distribution of related groups or broad groups is used. The 
sector-wise PFCE is divided into expenditure classes by applying the relative sector-wise expenditure of each class.

Table 3. Household Categories Based on Expenditure

\begin{tabular}{llll}
\hline & \multicolumn{1}{c}{ Rural } & & \multicolumn{1}{c}{ Urban } \\
\hline ERH1 & $000-255$ & EUH1 & $000-350$ \\
ERH2 & $255-340$ & EUH2 & $350-500$ \\
ERH3 & $340-525$ & EUH3 & $500-915$ \\
ERH4 & $525-775$ & EUH4 & $915-1500$ \\
ERH5 & $775-$ above & EUH5 & $1500-$ above \\
\hline
\end{tabular}

4.4 Distribution of Household Income by Source of Income and by Wage and Other Components

Data on the distribution of income and expenditure by occupation category are available from the income and expenditure survey conducted by NCAER for 2004-05. The ratio of income to expenditure as given by NCAER has been applied to category-wise expenditure as obtained by the NSSO $61^{\text {st }}$ Round to calculate the income of respective households' categories. The income of each household category is adjusted pro rata to equate the total household income with total personal income, as obtained from NAS 2009. The household income from the rest of the world and the government (i.e. transfer payment), as obtained from NAS 2009, has been divided in the same proportion as in the 2003-04 SAM by Saluja and Yadav (2006) for different household categories based on source of income. After subtracting both of these components from the personal income of different household groups, the remainder has been divided in the same proportion as in the SAM for 2003-04 for labour (i.e. wage) and capital (i.e. rent). To balance the sum total of the columns of labour and capital with the respective row totals, the unbalanced amount has been proportionately divided among different households. It has caused an insignificant rise (i.e. 0.05 per cent) in the total personal income as obtained from NAS 2009.

\section{Some Analytical Aspects}

To look into some analytical aspects, the present SAM is aggregated into four sectors, namely primary (sectors 1-7 and 11), secondary (sectors 12-14 and sectors 16-29 and 31), tertiary sectors (sectors 32-41) and energy and electricity sectors (sectors 8-10, 15 and 30). The patterns of intermediate demand in the different sectors of various years are shown in Table 4.The share of intermediate demand in terms of total intermediate demand of the primary sector from the sector itself has declined from 47.3 percent in 1973-74 to 34.6 percent in 2005-06. Similarly, primary sector intermediate demand from the secondary, tertiary and energy sectors has declined over the years The share of intermediate intra-sector demand in the secondary, tertiary and energy sectors rose between 1973-74 and 2005-06. 
Table 4. Pattern of Intermediate Demand

\begin{tabular}{|c|c|c|c|c|c|c|}
\hline Sectors & Year & $\begin{array}{c}\text { Primary } \\
\text { Sectors }\end{array}$ & $\begin{array}{c}\text { Secondary } \\
\text { Sectors }\end{array}$ & $\begin{array}{l}\text { Tertiary } \\
\text { Sectors }\end{array}$ & $\begin{array}{l}\text { Energy } \\
\text { Sectors }\end{array}$ & Total \\
\hline \multirow[t]{7}{*}{ Primary sectors } & $1973-74$ & 47.3 & 44.6 & 8.1 & 0.0 & 100 \\
\hline & $1983-84$ & 48.4 & 43.9 & 7.7 & 0.0 & 100 \\
\hline & $1993-94$ & 41.2 & 48.7 & 9.7 & 0.4 & 100 \\
\hline & 1994-95 & 38.7 & 53.8 & 7.4 & 0.1 & 100 \\
\hline & 1998-99 & 30.3 & 59.3 & 10.1 & 0.2 & 100 \\
\hline & 2003-04 & 41.6 & 48.3 & 9.9 & 0.1 & 100 \\
\hline & 2005-06 & 34.6 & 52.8 & 12.5 & 0.2 & 100 \\
\hline \multirow[t]{7}{*}{ Secondary sectors } & $1973-74$ & 11.1 & 68.9 & 18.5 & 1.5 & 100 \\
\hline & 1983-84 & 13.7 & 66.2 & 18.1 & 2.0 & 100 \\
\hline & $1993-94$ & 7.5 & 69.6 & 20.5 & 2.4 & 100 \\
\hline & 1994-95 & 8.4 & 71.9 & 17.5 & 2.1 & 100 \\
\hline & 1998-99 & 7.4 & 68.7 & 21.4 & 2.5 & 100 \\
\hline & 2003-04 & 5.4 & 75.5 & 16.6 & 2.6 & 100 \\
\hline & 2005-06 & 4.6 & 78.5 & 14.3 & 2.5 & 100 \\
\hline \multirow[t]{7}{*}{ Tertiary sectors } & $1973-74$ & 9.1 & 58.0 & 30.6 & 2.3 & 100 \\
\hline & $1983-84$ & 11.6 & 47.9 & 35.8 & 4.7 & 100 \\
\hline & 1993-94 & 9.6 & 51.5 & 32.9 & 6.0 & 100 \\
\hline & 1994-95 & 6.6 & 53.7 & 34.0 & 5.7 & 100 \\
\hline & 1998-99 & 6.9 & 47.5 & 39.1 & 6.4 & 100 \\
\hline & 2003-04 & 7.9 & 51.8 & 34.6 & 5.6 & 100 \\
\hline & 2005-06 & 7.3 & 54.1 & 33.6 & 4.9 & 100 \\
\hline \multirow[t]{7}{*}{ Energy sectors } & $1973-74$ & 13.5 & 31.6 & 15.3 & 39.5 & 100 \\
\hline & $1983-84$ & 7.5 & 30.8 & 19.1 & 42.7 & 100 \\
\hline & $1993-94$ & 6.2 & 31.3 & 25.5 & 37.0 & 100 \\
\hline & 1994-95 & 4.2 & 44.8 & 20.1 & 30.9 & 100 \\
\hline & 1998-99 & 3.0 & 31.8 & 28.5 & 36.8 & 100 \\
\hline & 2003-04 & 4.3 & 31.7 & 24.9 & 39.0 & 100 \\
\hline & 2005-06 & 4.1 & 28.6 & 23.3 & 44.0 & 100 \\
\hline
\end{tabular}

Sources: Figures pertaining to 1994-95 calculated from the SAM by (Pradhan et al, 1999) and 2005-06 are given in the present study and for other years taken from CSO I-O table.

Table 5 shows that the size of the total input as a proportion of total output over the period has increased from 37.5 percent in 1973-74 to 44.5 percent in 2005-06. The share of the primary sector itself has declined from 16.7 percent in 1973-74 to 13.7 percent in 2005-06. On the other hand, the share of the secondary sector, the tertiary and energy sectors have gone up. 
Table 5. Pattern of Technological Change: Input as Percentage of Output

\begin{tabular}{|c|c|c|c|c|c|c|}
\hline Sectors & Year & $\begin{array}{c}\text { Primary } \\
\text { Sectors }\end{array}$ & $\begin{array}{c}\text { Secondary } \\
\text { Sectors }\end{array}$ & $\begin{array}{l}\text { Tertiary } \\
\text { Sectors }\end{array}$ & $\begin{array}{l}\text { Energy } \\
\text { Sectors }\end{array}$ & Total \\
\hline \multirow[t]{7}{*}{ Primary sectors } & $1973-74$ & 16.7 & 18.0 & 4.5 & 0.0 & 13.8 \\
\hline & 1983-84 & 16.9 & 11.8 & 2.6 & 0.1 & 9.8 \\
\hline & 1993-94 & 14.3 & 10.1 & 2.1 & 0.5 & 7.6 \\
\hline & 1994-95 & 14.5 & 9.1 & 1.8 & 0.1 & 7.4 \\
\hline & 1998-99 & 11.6 & 11.7 & 1.9 & 0.2 & 7.3 \\
\hline & 2003-04 & 19.1 & 8.7 & 1.8 & 0.1 & 7.1 \\
\hline & 2005-06 & 13.7 & 6.2 & 2.0 & 0.1 & 5.3 \\
\hline \multirow[t]{7}{*}{ Secondary sectors } & $1973-74$ & 4.0 & 28.2 & 10.5 & 9.0 & 14.0 \\
\hline & 1983-84 & 8.4 & 31.3 & 10.6 & 5.8 & 17.3 \\
\hline & 1993-94 & 5.8 & 32.1 & 9.8 & 6.5 & 16.9 \\
\hline & 1994-95 & 7.0 & 27.0 & 9.6 & 5.0 & 16.4 \\
\hline & 1998-99 & 6.5 & 31.1 & 9.5 & 6.5 & 16.7 \\
\hline & 2003-04 & 6.4 & 35.4 & 8.0 & 6.3 & 18.4 \\
\hline & 2005-06 & 6.7 & 33.2 & 8.5 & 5.8 & 19.3 \\
\hline \multirow[t]{7}{*}{ Tertiary sectors } & $1973-74$ & 1.8 & 12.9 & 9.4 & 7.6 & 7.6 \\
\hline & 1983-84 & 4.7 & 14.8 & 13.7 & 8.9 & 11.3 \\
\hline & 1993-94 & 6.0 & 19.1 & 12.7 & 13.2 & 13.6 \\
\hline & 1994-95 & 4.2 & 15.6 & 14.5 & 10.7 & 12.7 \\
\hline & 1998-99 & 5.0 & 18.0 & 14.4 & 14.2 & 13.9 \\
\hline & 2003-04 & 7.3 & 18.7 & 12.9 & 10.4 & 14.1 \\
\hline & 2005-06 & 6.8 & 14.9 & 12.9 & 7.4 & 12.6 \\
\hline \multirow[t]{7}{*}{ Energy sectors } & $1973-74$ & 0.8 & 2.1 & 1.4 & 39.5 & 2.3 \\
\hline & $1983-84$ & 1.6 & 5.0 & 3.9 & 42.9 & 6.0 \\
\hline & 1993-94 & 1.8 & 5.5 & 4.7 & 39.1 & 6.5 \\
\hline & 1994-95 & 1.4 & 6.7 & 4.4 & 29.8 & 6.5 \\
\hline & 1998-99 & 1.0 & 5.7 & 4.9 & 38.2 & 6.6 \\
\hline & 2003-04 & 2.5 & 7.1 & 5.8 & 44.8 & 8.8 \\
\hline & 2005-06 & 2.3 & 4.6 & 5.2 & 38.5 & 7.3 \\
\hline \multirow[t]{7}{*}{ Total Input } & 1973-74 & 23.2 & 61.2 & 25.7 & 56.2 & 37.5 \\
\hline & 1983-84 & 31.5 & 62.9 & 30.8 & 57.6 & 44.3 \\
\hline & 1993-94 & 28.0 & 66.8 & 29.3 & 59.3 & 44.6 \\
\hline & 1994-95 & 27.0 & 58.5 & 30.3 & 45.6 & 43.0 \\
\hline & 1998-99 & 24.1 & 66.5 & 30.8 & 59.1 & 44.4 \\
\hline & 2003-04 & 35.2 & 70.0 & 28.6 & 61.6 & 48.3 \\
\hline & 2005-06 & 29.5 & 59.0 & 28.7 & 51.8 & 44.5 \\
\hline
\end{tabular}

Sources: Figures pertaining to 1994-95 calculated from the SAM by (Pradhan et al, 1999) and 2005-06 are given in the present study and for other years taken from CSO I-O table. 


\section{Concluding Remarks}

In this paper, we have constructed a SAM for the Indian economy for the year 2005-06 by both occupational and expenditure categories of households. We have put emphasis on the energy sectors in India. The specific characteristics of our SAM are as follows. First, we have converted the I-O table from 2006-07 to 2005-06 for different sectors. Second, Our SAM has separated column wise the electricity sector into three sub categories such as thermal, hydro and nuclear electricity. Third, the expenditure distribution is based on the NSSO $61^{\text {st }}$ Round survey on consumption expenditure for the year 2004-05. Finally, we have also used the income distribution data, available for the latest year, obtained from the household survey conducted by the NCAER for the year 2004-05.

Besides the subdivision of electricity sector, the other energy sector has also been divided into coal and lignite, crude oil and natural gas, and petroleum products, which will be useful for energy modeling. The expenditure wise division of households will help in modeling inclusive growth issues. This SAM can be significantly extended to include elements such as environmental quality, pollutants and natural resources and their interactions with economic activities.

\section{Acknowledgement}

This paper is part of the POEM project which was supported through the SEVENTH FRAMEWORK PROGRAMME for Research and Technological Development of European Union.

\section{References}

Bhide, S., \& Pohit, S. (1993). Forecasting and policy analysis through a CGE model for India. Margin, NCAER, New Delhi, 25,271-285

Central Statistical Organization. (1989). National Accounts Statistics: Sources and Methods. Government of India. Retrieved from http://mospi.nic.in/Mospi_New/site/home.aspx

Central Statistical Organization. (1994). National Accounts Statistics: Factor Incomes, 1980-81-1989-90. Retrieved from Government of India. Retrieved from http://mospi.nic.in/Mospi_New/site/home.aspx

Central Statistical Organization. (2005). Operational Characteristics of Unorganized Manufacturing Enterprises in India, Report No-524. Government of India. Retrieved from http://mospi.nic.in/Mospi_New/site/inner.aspx?status=3\&menu_id=84

Central Statistical Organization. (2009). Input Output Transactions table (2006-07). Government of India. Retrieved from http://mospi.nic.in/Mospi_New/site/inner.aspx?status=3\&menu_id=84

Central Statistical Organization. (2009). National Accounts Statistics. Government of India. 
Retrieved from http://mospi.nic.in/Mospi_New/site/inner.aspx?status=3\&menu_id=84

De, Janvry A., \& Subbarao, K. (1986). Agricultural Price Policy and Income Distribution in India. Oxford University Press, New Delhi.

Defourny, J., \& Thorbecke, E. (1984). Structural Path Analysis and Multiplier Decomposition within a Social Accounting Matrix. Economic Journal, 94, 111-136. http://dx.doi.org/10.2307/2232220

Handbook of Statistics on Indian Economy (2006-07). Reserve Bank of India (RBI). Retrieved from http://www.rbi.org.in/scripts/AnnualPublications.aspx?head=Handbook\%20of\%20Statis tics\%20on\%20Indian\%20Economy

Hayden, C., \& Round, J.I. (1982). Developments in Social Accounting Methods as Applied to the Analysis of Income Distribution and Employment Issues. World Development, 10, 451-65. http://dx.doi.org/10.1016/0305-750X(82)90002-X

Kumar, K. S., \& Parikh, J. (1996). Potential Impacts of Global Climate Change on Indian Agriculture. Communicated to Global Environment Change, 1996

National Sample Survey Organization. (2004-05) Household Consumption Expenditure among socio economic groups. Government of India. Retrieved from http://mospi.nic.in/Mospi_New/site/inner.aspx?status=4\&menu_id=63

Ojha, V.P., Pal, B.D., Pohit. S., \& Roy, J. (2009). Social Accounting Matrix for India. Retrieved from http://ssrn.com/abstract $=1457628$

Pal, B. D., Pohit, S., \& Roy, J. (2012). A social accounting matrix for India. Economic Systems Research, 24, 77-99. http://dx.doi.org/10.1080/09535314.2011.618824

Parikh, J., Panda, M., Ganesh-Kumar, A., \& Singh, V. (2009). CO2 emissions structure of Indian economy. Energy, 30, 1-7

Pohit, S. (1997). The Impact of Climate Change on Indians Agriculture: Some preliminary Observations. Proceeding of the 20th International Conference of the International Association for Energy Economics, 22-24 ${ }^{\text {th }}$ January, Delhi, India

Powell M., \& Round, J. I. (2000). Structure and Linkage in the Economy of Ghana: A SAM Approach. In E Aryeetey, J Harrigan and M Nissanke (eds), Economic Reforms in Ghana: Miracle or Mirage, James Currey Press, Oxford: 68-87.

Pradhan, B. K., Sahoo, A., \& Saluja, M.R. (1999). A social accounting matrix for India. 1994- 95. Economic and Political Weekly, 34(48), 3378-3394.

Pradhan, B.K., \& Roy, P.K. (2003). The Well Being of Indian Households: MIMAP - India Survey Report. Tata McGraw Hill, New Delhi.

Pradhan, B.K., Saluja, M. R., \& Sharma, A.K. (2013). A Social Accounting Matrix for India 2006-07, IEG Working Paper No. 326. Retrieved from 
http://www.iegindia.org/workpap/wp326.pdf

Pradhan, B.K., Saluja, M.R., \& Singh, S.K. (2006). Social Accounting Matrix for India, Concepts, construction and Applications. Sage Publications, New Delhi.

Pyatt, G., \& Round .J.I. (1979). Accounting and Fixed Price Multipliers in a SAM Framework. Economic Journal, 89, 850-873. http://dx.doi.org/10.2307/2231503

Ravindranath, N H., Joshi, N V., Sukumar, R., \& Saxena, A. (2006). Impact of Climate change on Forests in India. Current Science, 90, 354-361.

Saluja, M R., \& Yadav, B. (2006). The Social Accounting Matrix of India. Planning Commission, Government of India. Retrieved from http://planningcommission.nic.in/reports/sereport/ser/sr_sam.pdf

Sarkar, H., \& Subbarao, S.V. (1981). A short term Macro-forecasting Model for India: Structure and Use. Indian Economic Review, 16, 55-80.

Sarkar, H.K., \& Panda, M. (1986). Quantity-Price Money Interaction in a CGE Model. Margin, NCAER, New Delhi, 18, 31-47

Thorbecke, E., Downey. R., Keuning. S., Roland-Holst. D., \& Berrian. D. (1992). Adjustment and Equity in Indonesia, OECD Development Centre, Paris. 
APPENDIX TABLE 1: SAM 2005-06 for India by Occupation Classes

\begin{tabular}{|c|c|c|c|c|c|c|c|c|c|c|}
\hline Production sectors & $\mathrm{S} 1$ & $\mathrm{~S} 2$ & S3 & $\mathrm{S} 4$ & S5 & S6 & S7 & S8 & S9 & $\mathrm{S} 10$ \\
\hline S1 & 3395595 & 47276 & 297 & 276103 & 45231 & 44 & 482 & 0 & 0 & 0 \\
\hline S2 & 59551 & 2232453 & 4 & 350610 & 13536 & 1 & 6 & 0 & 0 & 0 \\
\hline S4 & 52019 & 109361 & 10 & 1681595 & 2552907 & 146 & 7 & 0 & 0 & 1 \\
\hline S5 & 611480 & 76125 & 583765 & 1042640 & 29452 & 8 & 87 & 0 & 0 & 1 \\
\hline S7 & 288 & 1004 & 0 & 2221 & 0 & 0 & 231483 & 0 & 0 & 0 \\
\hline S8 & 45 & 24 & 9 & 61 & 1254 & 2 & 0 & 11203 & 11 & 910 \\
\hline S9 & 0 & 0 & 0 & 0 & 151 & 0 & 0 & 0 & 50252 & 1264 \\
\hline S10 & 0 & 0 & 0 & 0 & 878 & 0 & 0 & 0 & 0 & 5 \\
\hline S14 & 338 & 400 & 152 & 738 & 443 & 186 & 6482 & 29683 & 3 & 1957 \\
\hline S15 & 415094 & 163027 & 172304 & 402610 & 1426 & 28077 & 150008 & 41651 & 88916 & 10516 \\
\hline S16 & 0 & 0 & 0 & 0 & 226 & 0 & 0 & 0 & 0 & 8 \\
\hline S17 & 837 & 882 & 330 & 2724 & 16685 & 6849 & 9380 & 299060 & 62730 & 26189 \\
\hline S18 & 2645 & 2217 & 1264 & 3501 & 960 & 2724 & 0 & 6408 & 4 & 439 \\
\hline S19 & 1461607 & 1115832 & 763611 & 1504785 & 166 & 349 & 206 & 0 & 0 & 3 \\
\hline S20 & 0 & 0 & 0 & 0 & 74 & 7 & 0 & 0 & 787 & 58 \\
\hline S21 & 1 & 1 & 0 & 118 & 366 & 13 & 0 & 0 & 50303 & 4516 \\
\hline S22 & 0 & 0 & 0 & 1 & 345 & 9 & 6447 & 2 & 1142 & 92 \\
\hline S28 & 11027 & 6050 & 2565 & 6844 & 1396 & 9267 & 2 & 21082 & 31 & 1931 \\
\hline S29 & 281970 & 153708 & 79541 & 229058 & 5454 & 26225 & 40 & 29991 & 275241 & 16618 \\
\hline S30A & 294553 & 249049 & 43249 & 148069 & 1556 & 519 & 42 & 107822 & 27131 & 14435 \\
\hline S30B & 9433 & 7976 & 1385 & 4742 & 50 & 17 & 1 & 3453 & 869 & 462 \\
\hline S30C & 42536 & 35965 & 6245 & 21382 & 225 & 75 & 6 & 15570 & 3918 & 2084 \\
\hline S31 & 56 & 41 & 33 & 61 & 6 & 222 & 0 & 1834 & 0 & 121 \\
\hline S32 & 195064 & 41701 & 25221 & 68442 & 25695 & 5884 & 2428 & 8213 & 3224 & 1646 \\
\hline S33 & 414886 & 238035 & 162280 & 377783 & 423538 & 83029 & 54370 & 139830 & 47660 & 15600 \\
\hline S34 & 29654 & 16538 & 6240 & 13931 & 1974 & 364 & 2024 & 668 & 995 & 140 \\
\hline S35 & 908 & 1162 & 273 & 2772 & 29290 & 199 & 50 & 833 & 470 & 100 \\
\hline S36 & 35874 & 20654 & 13519 & 32560 & 50678 & 354 & 4377 & 4431 & 3101 & 533 \\
\hline S37 & 95 & 63 & 49 & 85 & 0 & 0 & 0 & 0 & 0 & 0 \\
\hline S38 & 799609 & 432483 & 277907 & 830622 & 2009642 & 76611 & 53105 & 177169 & 176522 & 25579 \\
\hline S39 & 0 & 0 & 0 & 0 & 0 & 0 & 0 & 0 & 0 & 0 \\
\hline
\end{tabular}




\begin{tabular}{|c|c|c|c|c|c|c|c|c|c|c|}
\hline S40 & 0 & 0 & 0 & 0 & 0 & 0 & 0 & 0 & 0 & 0 \\
\hline Labour & 3853026 & 2420477 & 4430677 & 13939693 & 8733807 & 1360788 & 1945576 & 1036488 & 911385 & 244392 \\
\hline \multicolumn{11}{|l|}{ RH1 } \\
\hline \multicolumn{11}{|l|}{ RH2 } \\
\hline \multicolumn{11}{|l|}{ RH4 } \\
\hline \multicolumn{11}{|l|}{ RH5 } \\
\hline \multicolumn{11}{|l|}{ UH1 } \\
\hline \multicolumn{11}{|l|}{ UH2 } \\
\hline \multicolumn{11}{|l|}{ UH4 } \\
\hline \multicolumn{11}{|l|}{ Public Enterprises } \\
\hline \multicolumn{11}{|l|}{ Government } \\
\hline Indirect taxes & -1073623 & -1082192 & -504687 & -1034144 & 28278 & 10799 & -190533 & 89364 & 74865 & 12136 \\
\hline \multicolumn{11}{|l|}{ Capital a/c } \\
\hline Rest of the world & 45 & 18267 & 207251 & 631149 & 24437 & 472651 & 13649 & 877525 & 11794187 & 596819 \\
\hline Total & 14092490 & 8328486 & 10508940 & 31777115 & 21223617 & 3304812 & 3789578 & 5451719 & 15829947 & 1545409 \\
\hline Production sectors & S11 & S12 & $\mathrm{S} 13$ & S14 & $\mathrm{S} 15$ & S16 & S17 & S18 & S19 & S20 \\
\hline S7 & 0 & 380829 & 80 & 1 & 0 & 0 & 4382 & 209 & 223 & 0 \\
\hline S8 & 19911 & 22812 & 23499 & 5953 & 1975 & 178237 & 147295 & 50100 & 33104 & 197557 \\
\hline S9 & 61 & 160 & 10 & 38 & 15111689 & 308069 & 122573 & 497 & 0 & 1 \\
\hline S10 & 1151 & 9658 & 32952 & 95 & 1892 & 110 & 274662 & 863 & 376190 & 32710 \\
\hline S11 & 25262 & 4476 & 3215 & 445 & 778 & 2467 & 159991 & 3564 & 160392 & 337466 \\
\hline S12 & 297 & 3544965 & 11037 & 3187 & 1295 & 125 & 339963 & 10057 & 12052 & 185 \\
\hline S13 & 2927 & 87499 & 5179982 & 10197 & 2749 & 647 & 303087 & 18160 & 9282 & 8540 \\
\hline S14 & 2238 & 141356 & 72185 & 25625 & 7089 & 911 & 218177 & 81743 & 25120 & 26351 \\
\hline S15 & 52580 & 330287 & 386239 & 10080 & 785441 & 29392 & 985247 & 85112 & 775522 & 114895 \\
\hline S16 & 2193 & 599 & 452 & 77 & 381 & 24513 & 35382 & 372 & 689 & 2828 \\
\hline S17 & 95467 & 942949 & 2059191 & 93578 & 361549 & 73259 & 13294896 & 442327 & 1208765 & 124347 \\
\hline S18 & 1787 & 367907 & 141662 & 22782 & 10318 & 1181 & 280970 & 1324928 & 5215 & 34467 \\
\hline S19 & 224 & 50138 & 445 & 6582 & 2950 & 106 & 208392 & 68 & 545537 & 0 \\
\hline S20 & 701 & 64 & 426 & 46 & 2506 & 447 & 6237 & 28 & 76 & 1290 \\
\hline S21 & 5871 & 5903 & 5250 & 1376 & 1015 & 1618 & 39686 & 6717 & 1624 & 150700 \\
\hline
\end{tabular}




\begin{tabular}{|c|c|c|c|c|c|c|c|c|c|c|}
\hline S22 & 4767 & 980 & 12081 & 36871 & 950 & 967 & 203971 & 13710 & 3921 & 95 \\
\hline S23 & 37329 & 4946 & 6010 & 6447 & 1355 & 6481 & 201290 & 6672 & 5924 & 159 \\
\hline S24 & 36243 & 18152 & 34573 & 20309 & 933 & 412 & 112063 & 12366 & 1840 & 124 \\
\hline S25 & 21845 & 216935 & 508839 & 13891 & 25652 & 5407 & 262708 & 13636 & 16252 & 4601 \\
\hline S26 & 2099 & 10048 & 23783 & 20781 & 752 & 11 & 128726 & 24149 & 4497 & 141 \\
\hline S27 & 1954 & 5391 & 3526 & 4730 & 107 & 4 & 32722 & 243 & 227 & 0 \\
\hline S28 & 3685 & 14291 & 129733 & 6511 & 9447 & 375 & 205496 & 25899 & 5079 & 3330 \\
\hline S29 & 49392 & 281910 & 388975 & 5511 & 148763 & 11559 & 220230 & 55572 & 48813 & 8391 \\
\hline S30A & 52533 & 189745 & 595854 & 17404 & 236809 & 14294 & 675554 & 117320 & 82787 & 233478 \\
\hline S30B & 1682 & 6077 & 19083 & 557 & 7584 & 458 & 21635 & 3757 & 2651 & 7477 \\
\hline S30C & 7586 & 27401 & 86046 & 2513 & 34197 & 2064 & 97555 & 16942 & 11955 & 33716 \\
\hline S31 & 315 & 5484 & 3283 & 91 & 160 & 17 & 10353 & 30 & 1847 & 5 \\
\hline S32 & 11166 & 70221 & 24388 & 5052 & 373235 & 63184 & 136796 & 23662 & 36927 & 127276 \\
\hline S33 & 36040 & 1263098 & 1810276 & 55895 & 64062 & 29580 & 1202886 & 296838 & 231904 & 111604 \\
\hline S34 & 1063 & 77357 & 6241 & 3837 & 7916 & 3979 & 27277 & 5021 & 11886 & 11806 \\
\hline S35 & 162 & 14370 & 30401 & 465 & 2850 & 137 & 34273 & 14066 & 898 & 539 \\
\hline S36 & 2240 & 121726 & 206775 & 5958 & 5150 & 3855 & 133057 & 32469 & 23953 & 12266 \\
\hline S37 & 0 & 3 & 0 & 0 & 0 & 0 & 0 & 0 & 0 & 0 \\
\hline S38 & 209624 & 4799879 & 4334160 & 194999 & 654593 & 139756 & 3493184 & 468445 & 574987 & 347450 \\
\hline S39 & 0 & 0 & 0 & 0 & 0 & 0 & 0 & 0 & 0 & 0 \\
\hline S40 & 0 & 0 & 0 & 0 & 0 & 0 & 0 & 0 & 0 & 0 \\
\hline S41 & 0 & 0 & 0 & 0 & 0 & 0 & 0 & 0 & 0 & 0 \\
\hline Labour & 738304 & 1447910 & 2708839 & 232558 & 153585 & 29051 & 2026546 & 461505 & 320783 & 187956 \\
\hline Capital & 1607143 & 3431354 & 3708466 & 460910 & 3741863 & 123717 & 6902975 & 882199 & 891771 & 608497 \\
\hline \multicolumn{11}{|l|}{ RH1 } \\
\hline \multicolumn{11}{|l|}{ RH2 } \\
\hline \multicolumn{11}{|l|}{ RH3 } \\
\hline \multicolumn{11}{|l|}{ RH4 } \\
\hline \multicolumn{11}{|l|}{ RH5 } \\
\hline \multicolumn{11}{|l|}{ UH1 } \\
\hline \multicolumn{11}{|l|}{ UH2 } \\
\hline \multicolumn{11}{|l|}{ UH3 } \\
\hline \multicolumn{11}{|l|}{ UH4 } \\
\hline \multicolumn{11}{|l|}{ Private } \\
\hline \multicolumn{11}{|l|}{ corporations } \\
\hline \multicolumn{11}{|l|}{ Public Enterprises } \\
\hline \multicolumn{11}{|l|}{ Government } \\
\hline Indirect taxes & 49108 & 621566 & 448180 & 46057 & 1238672 & 41740 & 2292966 & 368724 & 288662 & 100638 \\
\hline \multicolumn{11}{|l|}{ Capital a/c } \\
\hline Rest of the world & 7178289 & 2909337 & 1230443 & 87772 & 1789001 & 1846363 & 7029198 & 869715 & 368852 & 902410 \\
\hline Total & 10263352 & 30592456 & 26528480 & 1700365 & 24791664 & 2945157 & 43164112 & 5973436 & 6106510 & 3733468 \\
\hline
\end{tabular}




\begin{tabular}{|c|c|c|c|c|c|c|c|c|c|c|}
\hline Production sectors & $\mathrm{S} 21$ & $\mathrm{~S} 22$ & S23 & S24 & S25 & S26 & S27 & S28 & S29 & S30A \\
\hline S1 & 11 & 2 & 1 & 67 & 425 & 26 & 0 & 925 & 92 & 222 \\
\hline S2 & 20 & 0 & 2 & 55 & 829 & 49 & 0 & 1785 & 56 & 227 \\
\hline S4 & 2665 & 696 & 302 & 3047 & 4927 & 3863 & 4987 & 12202 & 933142 & 2853 \\
\hline S5 & 882 & 110 & 632 & 1886 & 4380 & 7671 & 5206 & 23112 & 526670 & 447 \\
\hline S7 & 10 & 0 & 1 & 28 & 452 & 66 & 0 & 972 & 30 & 120 \\
\hline S8 & 92566 & 1623792 & 359952 & 343592 & 28555 & 38463 & 23607 & 17034 & 2071 & 1580780 \\
\hline S9 & 1639 & 16401 & 841 & 2248 & 156 & 2545 & 161 & 79232 & 23 & 38563 \\
\hline S10 & 8324 & 251614 & 20859 & 42821 & 22519 & 4481 & 1268 & 2283 & 347 & 303851 \\
\hline S14 & 35056 & 15884 & 4158 & 27394 & 95851 & 120259 & 34501 & 41576 & 809620 & 4671 \\
\hline S15 & 480285 & 370940 & 75289 & 126523 & 145387 & 252621 & 112206 & 49891 & 987593 & 1067705 \\
\hline S16 & 26132 & 193857 & 36154 & 36240 & 1873 & 9235 & 2180 & 1694 & 1949867 & 46049 \\
\hline S17 & 303410 & 217240 & 193723 & 271463 & 439118 & 1763669 & 658887 & 426157 & 954176 & 33318 \\
\hline S18 & 57068 & 17582 & 7951 & 32353 & 53785 & 158815 & 26271 & 45639 & 76917 & 50679 \\
\hline S19 & 2872 & 4551 & 159 & 2133 & 80 & 5010 & 75 & 319 & 9968 & 2966 \\
\hline S20 & 73408 & 1412 & 949 & 2138 & 1178 & 2126 & 3639 & 963 & 3474730 & 107 \\
\hline S21 & 564300 & 45210 & 5417 & 25024 & 43928 & 253509 & 22211 & 25079 & 4903573 & 890 \\
\hline S28 & 39822 & 20171 & 27104 & 78403 & 182924 & 347298 & 211371 & 3013734 & 622210 & 255208 \\
\hline S29 & 471277 & 70593 & 54076 & 140922 & 383683 & 491461 & 129894 & 82344 & 3318361 & 282898 \\
\hline S30A & 285469 & 891711 & 152731 & 212186 & 173572 & 316021 & 270099 & 57635 & 808970 & 3426661 \\
\hline S30B & 9143 & 28558 & 4891 & 6796 & 5559 & 10121 & 8650 & 1846 & 25908 & 109743 \\
\hline S30C & 41224 & 128770 & 22056 & 30641 & 25065 & 45636 & 39004 & 8323 & 116822 & 494837 \\
\hline S31 & 883 & 139 & 67 & 273 & 481 & 265 & 18150 & 26 & 155168 & 17098 \\
\hline S32 & 56799 & 716748 & 120577 & 157248 & 68487 & 80140 & 57547 & 161019 & 799164 & 410299 \\
\hline S33 & 287430 & 448948 & 118291 & 197223 & 303137 & 676180 & 292461 & 325709 & 3346796 & 300786 \\
\hline S34 & 11644 & 38309 & 8744 & 9260 & 3005 & 4988 & 2604 & 11754 & 75110 & 39754 \\
\hline S35 & 1162 & 2398 & 566 & 2160 & 7614 & 18453 & 12095 & 10821 & 21047 & 4140 \\
\hline S36 & 23623 & 51973 & 13068 & 21094 & 27098 & 57573 & 25734 & 24395 & 318670 & 32775 \\
\hline S37 & 0 & 0 & 0 & 0 & 0 & 0 & 0 & 0 & 0 & 0 \\
\hline S38 & 608032 & 2393622 & 490841 & 897146 & 1982122 & 4366167 & 2214498 & 1289779 & 8411293 & 1702920 \\
\hline S39 & 0 & 0 & 0 & 0 & 0 & 0 & 0 & 0 & 0 & 0 \\
\hline S40 & 0 & 0 & 0 & 0 & 0 & 0 & 0 & 0 & 0 & 0 \\
\hline
\end{tabular}




\begin{tabular}{|c|c|c|c|c|c|c|c|c|c|c|}
\hline S41 & 0 & 0 & 0 & 0 & 0 & 0 & 0 & 0 & 0 & 0 \\
\hline Labour & 545873 & 964051 & 146609 & 830112 & 1252024 & 1064460 & 716006 & 1114099 & 22976095 & 3124210 \\
\hline Capital & 1673649 & 3799129 & 753492 & 1573192 & 2519121 & 2359731 & 2124910 & 2026289 & 5004535 & 488085 \\
\hline \multicolumn{11}{|l|}{ RH2 } \\
\hline \multicolumn{11}{|l|}{ RH3 } \\
\hline \multicolumn{11}{|l|}{ RH5 } \\
\hline \multicolumn{11}{|l|}{ UH1 } \\
\hline \multicolumn{11}{|l|}{ UH2 } \\
\hline \multicolumn{11}{|l|}{ UH3 } \\
\hline \multicolumn{11}{|l|}{ Government } \\
\hline Indirect taxes & 339731 & 749627 & 278044 & 554287 & 1088397 & 2324264 & 936927 & 438881 & 2160526 & -1313645 \\
\hline \multicolumn{11}{|l|}{ Capital a/c } \\
\hline Rest of the world & 433097 & 2540237 & 5030344 & 487238 & 3846268 & 5225335 & 2978970 & 18435972 & 0 & 0 \\
\hline Total & 7238366 & 22271146 & 9460960 & 9917479 & 20010065 & 35288304 & 15978167 & 29284631 & 79335145 & 13245670 \\
\hline
\end{tabular}

\begin{tabular}{|c|c|c|c|c|c|c|c|c|c|c|}
\hline Production sectors & S30B & S30C & S31 & S32 & S33 & S34 & S35 & S36 & S37 & S38 \\
\hline S1 & 3 & 41 & 3 & 0 & 15 & 104 & 0 & 0 & 0 & 615887 \\
\hline S2 & 3 & 42 & 0 & 0 & 1107 & 109 & 0 & 8 & 0 & 337049 \\
\hline S3 & 542 & 7732 & 728 & 0 & 0 & 0 & 2 & 0 & 0 & 130385 \\
\hline S4 & 42 & 523 & 115 & 0 & 820333 & 671 & 0 & 0 & 0 & 2030452 \\
\hline S5 & 7 & 82 & 3 & 0 & 0 & 0 & 0 & 0 & 0 & 1105391 \\
\hline S6 & 35 & 411 & 148 & 33 & 0 & 0 & 0 & 0 & 0 & 15594 \\
\hline S7 & 2 & 22 & 0 & 0 & 0 & 0 & 0 & 0 & 0 & 13783 \\
\hline S8 & 0 & 0 & 277 & 3617 & 0 & 0 & 0 & 0 & 0 & 16572 \\
\hline S9 & 0 & 0 & 159 & 0 & 0 & 0 & 3 & 6 & 0 & 11724 \\
\hline S10 & 0 & 0 & 139 & 0 & 0 & 0 & 0 & 0 & 0 & 5866 \\
\hline S11 & 74264 & 1118 & 19 & 0 & 0 & 0 & 0 & 0 & 0 & 12804 \\
\hline S12 & 35 & 562 & 645 & 0 & 16172 & 786 & 0 & 0 & 31 & 2133875 \\
\hline S13 & 76 & 1882 & 111 & 788 & 68121 & 881 & 39 & 248 & 1709 & 123466 \\
\hline S14 & 71 & 925 & 227 & 181 & 1017 & 84 & 87 & 457 & 3884 & 90257 \\
\hline S15 & 44094 & 386183 & 1902 & 232067 & 10419504 & 40833 & 76052 & 37878 & 2952 & 781855 \\
\hline S16 & 0 & 0 & 30 & 167 & 0 & 0 & 0 & 0 & 0 & 1458 \\
\hline S17 & 38323 & 6462 & 4314 & 436 & 1721120 & 162939 & 99809 & 38330 & 3126 & 380061 \\
\hline S18 & 760 & 10252 & 2551 & 9494 & 270049 & 1007 & 1374 & 117999 & 4092 & 828543 \\
\hline S19 & 44 & 544 & 1091 & 5 & 197 & 0 & 0 & 0 & 3029 & 9586 \\
\hline S20 & 2 & 20 & 0 & 0 & 0 & 0 & 0 & 0 & 119 & 492 \\
\hline S21 & 13 & 163 & 38 & 516 & 53385 & 0 & 0 & 0 & 134 & 28035 \\
\hline
\end{tabular}




\begin{tabular}{|c|c|c|c|c|c|c|c|c|c|c|}
\hline S22 & 192 & 2385 & 1907 & 332 & 713 & 0 & 0 & 78 & 591 & 173353 \\
\hline S23 & 223 & 2775 & 65 & 0 & 279 & 0 & 0 & 0 & 0 & 77637 \\
\hline S24 & 128 & 1586 & 1072 & 770 & 236145 & 774 & 38 & 24 & 619 & 137354 \\
\hline S25 & 2078 & 50225 & 2367 & 6464 & 377515 & 446 & 0 & 43 & 5574 & 137783 \\
\hline S26 & 6597 & 97385 & 1359 & 29262 & 409953 & 11263 & 4122 & 13649 & 92 & 1791461 \\
\hline S27 & 228 & 2836 & 653 & 708718 & 959416 & 89486 & 582 & 10544 & 509 & 302820 \\
\hline S28 & 3851 & 59050 & 2407 & 372259 & 556274 & 6340 & 70625 & 3 & 4897 & 1593324 \\
\hline S29 & 3856 & 67628 & 101492 & 704107 & 514792 & 32193 & 26481 & 92408 & 16990 & 2758160 \\
\hline S30A & 50635 & 643853 & 20178 & 551921 & 22110 & 4422 & 1711 & 78497 & 55813 & 514140 \\
\hline S30B & 1622 & 20620 & 646 & 17676 & 708 & 142 & 55 & 2514 & 1787 & 16466 \\
\hline S30C & 7312 & 92977 & 2914 & 79702 & 3193 & 639 & 247 & 11336 & 8060 & 74246 \\
\hline S31 & 258 & 3244 & 123057 & 278 & 13267 & 17208 & 769 & 5 & 276 & 93821 \\
\hline S32 & 6065 & 76533 & 606 & 491870 & 440373 & 1134 & 1083 & 1067 & 2354 & 92183 \\
\hline S33 & 4439 & 55252 & 5653 & 66428 & 1655039 & 60017 & 38948 & 379933 & 7752 & 2989007 \\
\hline S34 & 608 & 7841 & 42 & 2967 & 117275 & 472 & 898 & 421 & 50 & 48202 \\
\hline S35 & 61 & 759 & 154 & 1245 & 29671 & 160 & 247 & 5602 & 69 & 86346 \\
\hline S36 & 502 & 7196 & 163 & 1611 & 77455 & 964 & 796 & 3382 & 177 & 101601 \\
\hline S37 & 0 & 0 & 0 & 0 & 0 & 166 & 0 & 10462 & 0 & 355925 \\
\hline S38 & 25186 & 325271 & 77908 & 177123 & 6544281 & 154312 & 81497 & 543649 & 23032 & 15799007 \\
\hline S39 & 0 & 0 & 0 & 87448 & 0 & 0 & 0 & 0 & 0 & 149787 \\
\hline S40 & 0 & 0 & 0 & 10667 & 0 & 0 & 0 & 0 & 0 & 127894 \\
\hline S41 & 0 & 0 & 0 & 0 & 0 & 0 & 0 & 0 & 0 & 0 \\
\hline Labour & 235474 & 1358759 & 311655 & 2187696 & 8652313 & 559454 & 211606 & 951888 & 124077 & 36480438 \\
\hline Capital & 36787 & 212274 & 288385 & 1226643 & 5131548 & 331803 & 125500 & 564549 & 103345 & 78237921 \\
\hline \multicolumn{11}{|l|}{ RH1 } \\
\hline \multicolumn{11}{|l|}{ RH2 } \\
\hline \multicolumn{11}{|l|}{ RH3 } \\
\hline \multicolumn{11}{|l|}{ RH4 } \\
\hline \multicolumn{11}{|l|}{ RH5 } \\
\hline \multicolumn{11}{|l|}{ UH1 } \\
\hline \multicolumn{11}{|l|}{ UH2 } \\
\hline \multicolumn{11}{|l|}{ UH3 } \\
\hline \multicolumn{11}{|l|}{ UH4 } \\
\hline \multicolumn{11}{|l|}{ Private } \\
\hline \multicolumn{11}{|l|}{ corporations } \\
\hline \multicolumn{11}{|l|}{ Public Enterprises } \\
\hline \multicolumn{11}{|l|}{ Government } \\
\hline Indirect taxes & -49121 & -316283 & 7202 & 191468 & 2215127 & 41097 & 37399 & 43215 & 9072 & 650393 \\
\hline \multicolumn{11}{|l|}{ Capital a/c } \\
\hline Rest of the world & 0 & 0 & 0 & 0 & 437572 & 0 & 0 & 0 & 0 & 3586539 \\
\hline Total & 495297 & 3189129 & 962382 & 7163959 & 41766038 & 1519903 & 779973 & 2908195 & 384215 & 155048943 \\
\hline Production sectors & S39 & S40 & S41 & Labour & Capital & RH1 & RH2 & RH3 & RH4 & RH5 \\
\hline
\end{tabular}




\begin{tabular}{|c|c|c|c|c|c|c|c|c|}
\hline S1 & 3037 & 4841 & 0 & 1123360 & 1610415 & 633976 & 2396776 & 591648 \\
\hline S2 & 3809 & 5045 & 0 & 478793 & 452615 & 253385 & 1172888 & 266729 \\
\hline S3 & 0 & 0 & 0 & 255151 & 354786 & 171446 & 638970 & 129911 \\
\hline S4 & 11466 & 8104 & 0 & 2003626 & 2687671 & 1191862 & 4877036 & 1239782 \\
\hline S5 & 8692 & 4301 & 0 & 1514093 & 1222125 & 727015 & 4572394 & 1061071 \\
\hline S6 & 0 & 0 & 0 & 283535 & 473857 & 212274 & 749181 & 143286 \\
\hline S7 & 0 & 0 & 0 & 363110 & 322834 & 218737 & 601750 & 214524 \\
\hline S8 & 0 & 0 & 0 & 3847 & 584 & 1486 & 2956 & 3288 \\
\hline S9 & 0 & 0 & 0 & & & & & \\
\hline S10 & 0 & 0 & 0 & 5562 & 8650 & 333 & 67064 & 7000 \\
\hline S11 & 0 & 0 & 0 & & & & & \\
\hline S12 & 0 & 0 & 0 & 2453320 & 2823340 & 1528826 & 5420320 & 1791610 \\
\hline S13 & 14647 & 8229 & 0 & 1346644 & 1042226 & 611399 & 3209403 & 944364 \\
\hline S14 & 24905 & 5164 & 0 & 36447 & 11816 & 18499 & 39760 & 25195 \\
\hline S15 & 59483 & 28590 & 0 & 385755 & 28823 & 66982 & 766122 & 445111 \\
\hline S16 & 0 & 0 & 0 & 0 & 0 & 0 & 0 & 0 \\
\hline S17 & 1963639 & 11163 & 0 & 471402 & 568755 & 276625 & 1055485 & 337010 \\
\hline S18 & 59007 & 11249 & 0 & 77289 & 49844 & 34072 & 189402 & 93843 \\
\hline S19 & 0 & 0 & 0 & 0 & 0 & 0 & 0 & 0 \\
\hline S20 & 0 & 0 & 0 & & & & & \\
\hline S21 & 3 & 1 & 0 & 6213 & 6653 & 4690 & 19558 & 3827 \\
\hline S22 & 0 & 0 & 0 & & & & & \\
\hline S23 & 0 & 0 & 0 & & & & & \\
\hline S24 & 6349 & 4838 & 0 & 69333 & 97933 & 24975 & 152505 & 35619 \\
\hline S25 & 6218 & 3077 & 0 & 49301 & 40469 & 39657 & 80097 & 86473 \\
\hline S26 & 81829 & 1277 & 0 & 377966 & 294142 & 190839 & 1036935 & 265206 \\
\hline S27 & 10130 & 5011 & 0 & 158818 & 51532 & 34651 & 364902 & 134753 \\
\hline S28 & 71064 & 40272 & 0 & 115708 & 49855 & 48691 & 250892 & 144727 \\
\hline S29 & 186938 & 244091 & 0 & 212915 & 186905 & 109173 & 374908 & 205457 \\
\hline S30A & 13138 & 6741 & 0 & 181948 & 139557 & 83177 & 355079 & 159680 \\
\hline S30B & 421 & 216 & 0 & 5827 & 4469 & 2664 & 11372 & 5114 \\
\hline S30C & 1897 & 973 & 0 & 26275 & 20153 & 12011 & 51276 & 23059 \\
\hline S31 & 757 & 374 & 0 & 3196 & 2855 & 1729 & 6258 & 3604 \\
\hline S32 & 1399 & 1242 & 0 & 61278 & 29651 & 36205 & 76503 & 77251 \\
\hline S33 & 171273 & 329950 & 0 & 1828845 & 2117838 & 1486215 & 4084783 & 1694763 \\
\hline S34 & 785 & 424 & 0 & 142879 & 143121 & 63793 & 260917 & 26363 \\
\hline S35 & 32977 & 745 & 0 & 2711 & 30 & 24 & 689 & 300 \\
\hline S36 & 24201 & 858 & 0 & 84231 & 50671 & 22686 & 123632 & 59927 \\
\hline S37 & 0 & 0 & 0 & & & & & \\
\hline S38 & 639836 & 567040 & 0 & 5610710 & 4856465 & 2669674 & 16249879 & 4747276 \\
\hline S39 & 0 & 0 & 0 & 1023338 & 930998 & 554617 & 2227519 & 679964 \\
\hline S40 & 646 & 332 & 0 & 656733 & 353758 & 245075 & 1511868 & 747150 \\
\hline S41 & 0 & 0 & 0 & 0 & 0 & 0 & 0 & 0 \\
\hline
\end{tabular}




\begin{tabular}{|c|c|c|c|c|c|c|c|c|c|c|}
\hline Labour & 4364248 & 8806610 & 17783932 & & & & & & & \\
\hline Capital & 1845084 & 2466571 & 1958803 & & & & & & & \\
\hline RH1 & & & & 11419479 & 10280381 & & & & & \\
\hline RH2 & & & & 22010990 & 78204.625 & & & & & \\
\hline RH3 & & & & 11134926 & 736219.92 & & & & & \\
\hline RH4 & & & & 22595410 & 42119978 & & & & & \\
\hline RH5 & & & & 5065984.7 & 15818558 & & & & & \\
\hline UH1 & & & & 28695819 & 13106221 & & & & & \\
\hline UH2 & & & & 54381581 & 3777301.5 & & & & & \\
\hline UH3 & & & & 4755761.7 & 1001138.1 & & & & & \\
\hline UH4 & & & & 1621386.3 & 4917261.3 & & & & & \\
\hline \multicolumn{11}{|l|}{ Private } \\
\hline corporations & & & & & 25195200 & & & & & \\
\hline Public Enterprises & & & & & 7596700 & & & & & \\
\hline Government & & & & & 5942600 & 1582678 & & & 2948833 & 925485 \\
\hline Indirect taxes & 348257 & 23270 & 0 & & & 932089 & 842055 & 494465 & 2299584 & 771647 \\
\hline Capital a/c & & & & & 38031200 & 1386415 & 3291077 & 440628 & 15672495 & 6883948 \\
\hline Rest of the world & 0 & 0 & 0 & & & & & & & \\
\hline Total & 9956135 & 12590599 & 19742735 & 161681337 & 168600963 & 25321341 & 25168529 & 12512557 & 73919990 & 24975967 \\
\hline Production sectors & UH1 & UH2 & UH3 & UH4 & $\begin{array}{l}\text { Private } \\
\text { corporations }\end{array}$ & $\begin{array}{l}\text { Public } \\
\text { Enterprises }\end{array}$ & Government & $\begin{array}{l}\text { Indirect } \\
\text { taxes }\end{array}$ & Capital a/c & $\begin{array}{l}\text { Rest of the } \\
\text { world }\end{array}$ \\
\hline S1 & 829730 & 854788 & 233908 & 130178 & & & 93747 & & 276722 & 521958 \\
\hline $\mathrm{S} 2$ & 561809 & 506140 & 104762 & 71799 & & & 48512 & & 553775 & 83536 \\
\hline S3 & 296442 & 311991 & 71770 & 39712 & & & 0 & & 1083862 & 55764 \\
\hline S4 & 2261959 & 2350941 & 473958 & 366020 & & & 170027 & & 1686932 & 652115 \\
\hline S5 & 2183101 & 2127736 & 288469 & 323629 & & & 311143 & & 836714 & 241728 \\
\hline S6 & 106821 & 54888 & 62879 & 10616 & & & 56 & & 26065 & 212012 \\
\hline S7 & 276036 & 320186 & 77154 & 68935 & & & 0 & & 110825 & 579281 \\
\hline S8 & 6613 & 5590 & 2632 & 820 & & & 5787 & & 568780 & 24499 \\
\hline S9 & & & & & & & 0 & & 933 & 80547 \\
\hline S10 & 2653 & 2574 & 286 & 195 & & & 25046 & & -15531 & 46038 \\
\hline S11 & & & & & & & 0 & & -626172 & 4653542 \\
\hline S12 & 3196549 & 3712496 & 677743 & 761710 & & & 364090 & & -384599 & 1789337 \\
\hline S13 & 1694541 & 1810135 & 245736 & 291436 & & & 300504 & & 895577 & 7693204 \\
\hline S14 & 23956 & 43625 & 1979 & 3343 & & & 54714 & & -616664 & 100290 \\
\hline S15 & 1503629 & 1485112 & 26760 & 219219 & & & 385466 & & -3015208 & 1685635 \\
\hline S16 & 0 & 0 & 0 & 0 & & & 0 & & 523879 & 48619 \\
\hline S17 & 646583 & 724322 & 119160 & 120533 & & & 468162 & & 4679790 & 4883405 \\
\hline S18 & 168358 & 220159 & 11639 & 56664 & & & 436629 & & 384365 & 196355 \\
\hline S19 & 0 & 0 & 0 & 0 & & & 195 & & 205665 & 197021 \\
\hline S20 & & & & & & & 0 & & 149311 & 10126 \\
\hline S21 & 4369 & 4128 & 1007 & 667 & & & 375 & & 542367 & 398006 \\
\hline
\end{tabular}


S22

S23

S24

S25

S26

S27

S28

S29

S30A

S30B

S30C

S31

S32

S33

S34

S35

S36

S37

S38

S39

S40

S41

Labour

Capital

RH1

RH2

RH3

RH4

RH5

UH1

UH2

UH3

UH4

Private

corporations

Public Enterprises

Government

Indirect taxes

Capital a/c

Rest of the world

Total

\begin{tabular}{|c|c|c|c|}
\hline 85995 & 82783 & 9133 & 15368 \\
\hline 139166 & 341433 & 15452 & 52541 \\
\hline 407012 & 423901 & 59907 & 88229 \\
\hline 277778 & 426502 & 16121 & 100405 \\
\hline 274144 & 343168 & 20088 & 55546 \\
\hline 206087 & 548904 & 24135 & 35262 \\
\hline 565519 & 583911 & 55446 & 106615 \\
\hline 18111 & 18700 & 1776 & 3414 \\
\hline 81665 & 84321 & 8007 & 15396 \\
\hline 23195 & 25743 & 2215 & 4983 \\
\hline 196573 & 351479 & 28082 & 54984 \\
\hline 1943745 & 3230973 & 553469 & 499838 \\
\hline 8725 & 108151 & 13456 & 3001 \\
\hline 101314 & 3261 & 0 & 9321 \\
\hline 211277 & 237380 & 15417 & 45827 \\
\hline 7108828 & 10286639 & 819342 & 1591808 \\
\hline 1074189 & 1098527 & 219079 & 317078 \\
\hline 1699120 & 2145831 & 104269 & 429897 \\
\hline 0 & 0 & 0 & 0 \\
\hline
\end{tabular}

12240500

1593592

4557360

19742735

3265449

2596766

8913575

2796307

4397735

6615605

1065079

1406600

$1830769 \quad 2178772$

$1432754 \quad 1716044$

277464

10134300

$16081434 \quad 28534846$

184761

295640

3562324

16467500

(164000

(6)

$49530549 \quad 67306079 \quad 6277589 \quad 10030417 \quad 26601800$
0

51894

129656

401407

242350

144121

675387

499679

16003

72158

418784

134117

745828

17752

40593

33507

4143

618133

401021

$-643953$

$-291026$

1456031

10697880

14696004

8018931

6530379

64264403

$-1145358$

34406

1110952

(11095

315599

1205256

26487

153457

193550

0

4062539$$
0
$$

0

$-263700$

$-2347900$

356033

482568

23277

291028

1295117

3330775

2531592

119668

2426690

$-712349$

452666

28890492

6884075

$-63995523$

$-72712274$

52724726

9136656 


\begin{tabular}{|c|c|}
\hline S2 & 8328486 \\
\hline S3 & 10508939 \\
\hline S4 & 31777115 \\
\hline S5 & 21223617 \\
\hline S6 & 3304812 \\
\hline S7 & 3789577 \\
\hline S8 & 5451719 \\
\hline S9 & 15829946 \\
\hline S10 & 1545409 \\
\hline S11 & 10263352 \\
\hline S12 & 30592456 \\
\hline S13 & 26528480 \\
\hline S14 & 1700365 \\
\hline S15 & 24791664 \\
\hline S16 & 2945157 \\
\hline S17 & 43164112 \\
\hline S18 & 5973436 \\
\hline S19 & 6106510 \\
\hline S20 & 3733468 \\
\hline S21 & 7238365 \\
\hline S22 & 22271146 \\
\hline S23 & 9460960 \\
\hline S24 & 9917479 \\
\hline S25 & 20010065 \\
\hline S26 & 35288303 \\
\hline S27 & 15978168 \\
\hline S28 & 29284631 \\
\hline S29 & 79335144 \\
\hline S30A & 13245670 \\
\hline S30B & 495297 \\
\hline S30C & 3189129 \\
\hline S31 & 962383 \\
\hline S32 & 7163958 \\
\hline S33 & 41766038 \\
\hline S34 & 1519903 \\
\hline S35 & 779972 \\
\hline S36 & 2908195 \\
\hline S37 & 384215 \\
\hline S38 & 155048947 \\
\hline S39 & 9956135 \\
\hline S40 & 12590599 \\
\hline S41 & 19742735 \\
\hline Labour & 161681337 \\
\hline
\end{tabular}




\begin{tabular}{ll}
\hline Capital & 168600963 \\
RH1 & 25321341 \\
RH2 & 25168529 \\
RH3 & 12512557 \\
RH4 & 73919990 \\
RH5 & 24975967 \\
UH1 & 49530549 \\
UH2 & 67306079 \\
UH3 & 6277589 \\
UH4 & 10030417 \\
Private & \\
corporations & 26601800 \\
Public enterprises & 7596700 \\
Government & 53999043 \\
Indirect taxes & 28890492 \\
Capital a/c & 52724726 \\
Rest of the world & 9136656 \\
Total & \\
\hline
\end{tabular}

APPENDIX TABLE 2: Expenditure Classes for 2005-06

\begin{tabular}{|c|c|c|c|c|c|c|c|c|c|c|}
\hline $\begin{array}{l}\text { Production } \\
\text { sectors }\end{array}$ & ERH1 & ERH2 & ERH3 & ERH4 & ERH5 & EUH1 & EUH2 & EUH3 & EUH4 & EUH5 \\
\hline S1 & 489929 & 1154499 & 2496438 & 1435091 & 780218 & 143145 & 356508 & 813928 & 478894 & 256129 \\
\hline S2 & 162735 & 450517 & 1031188 & 609454 & 370516 & 98843 & 215302 & 491433 & 276783 & 162148 \\
\hline S3 & 64932 & 203162 & 580095 & 409323 & 292752 & 33403 & 90892 & 240983 & 188240 & 166396 \\
\hline S4 & 664593 & 1805514 & 4528790 & 2915285 & 2041874 & 280521 & 745284 & 2023408 & 1446823 & 1000764 \\
\hline S5 & 210314 & 847376 & 3143458 & 2735726 & 2227236 & 146469 & 513882 & 1710440 & 1409468 & 1075264 \\
\hline S6 & 128173 & 325725 & 768341 & 436401 & 203493 & 45588 & 78524 & 89783 & 16216 & 5093 \\
\hline S7 & 62524 & 187977 & 598987 & 488840 & 382628 & 27186 & 84848 & 245036 & 202221 & 183020 \\
\hline S8 & 307 & 1325 & 4468 & 3479 & 2582 & 1858 & 4257 & 6587 & 2149 & 804 \\
\hline \multicolumn{11}{|l|}{ S9 } \\
\hline S10 & 0 & 5716 & 15786 & 31632 & 35475 & 190 & 1006 & 1461 & 2499 & 552 \\
\hline \multicolumn{11}{|l|}{ S11 } \\
\hline S12 & 581970 & 1754237 & 4981812 & 3640339 & 3059059 & 312849 & 913221 & 2800139 & 2269624 & 2052666 \\
\hline S13 & 88864 & 400976 & 1805195 & 2086572 & 2772430 & 46161 & 250329 & 1040185 & 1189937 & 1515236 \\
\hline S14 & 135 & 209 & 9114 & 17658 & 104601 & 125 & 1138 & 7474 & 11452 & 52713 \\
\hline S15 & 1578 & 14921 & 200397 & 447042 & 1028855 & 2439 & 35292 & 589402 & 1035829 & 1571758 \\
\hline \multicolumn{11}{|l|}{ S16 } \\
\hline S17 & 130249 & 366838 & 988590 & 707025 & 516577 & 66118 & 191135 & 572765 & 441667 & 338912 \\
\hline S18 & 5118 & 23905 & 101137 & 131931 & 182359 & 3743 & 14802 & 101850 & 135820 & 200605 \\
\hline \multicolumn{11}{|l|}{ S19 } \\
\hline \multicolumn{11}{|l|}{ S20 } \\
\hline S21 & 1889 & 5532 & 14924 & 10862 & 7732 & 620 & 1554 & 4268 & 1995 & 1734 \\
\hline \multicolumn{11}{|l|}{ S22 } \\
\hline \multicolumn{11}{|l|}{ S23 } \\
\hline S24 & 4108 & 22152 & 103991 & 98286 & 151828 & 3341 & 14111 & 65650 & 58527 & 51651 \\
\hline S25 & 191 & 1829 & 27554 & 65429 & 200994 & 1803 & 5461 & 60454 & 105101 & 375772 \\
\hline S26 & 56254 & 207977 & 700755 & 615112 & 584990 & 24367 & 91199 & 311700 & 276356 & 275426 \\
\hline S27 & 4804 & 18340 & 72148 & 79756 & 569607 & 2852 & 11021 & 46948 & 67508 & 692478 \\
\hline
\end{tabular}




\begin{tabular}{|c|c|c|c|c|c|c|c|c|c|c|}
\hline S28 & 415 & 7022 & 76148 & 119650 & 414118 & 1576 & 6139 & 93937 & 205417 & 378398 \\
\hline S29 & 58735 & 147337 & 432370 & 309641 & 351936 & 16456 & 44075 & 151205 & 184274 & 207719 \\
\hline S30 & 24965 & 91631 & 340005 & 316137 & 308924 & 35009 & 129553 & 470851 & 448337 & 459132 \\
\hline S31 & 356 & 1193 & 5200 & 5151 & 5742 & 1123 & 4705 & 19560 & 17313 & 13434 \\
\hline S32 & 2070 & 15462 & 49564 & 73480 & 140312 & 5507 & 24838 & 155027 & 167371 & 278376 \\
\hline S33 & 272802 & 937640 & 3485758 & 3165336 & 3350909 & 142882 & 560872 & 2186354 & 1909693 & 1428225 \\
\hline S34 & 18378 & 65514 & 228938 & 181255 & 142987 & 1203 & 3672 & 22996 & 6820 & 98642 \\
\hline S35 & 0 & 30 & 182 & 243 & 3299 & 0 & 5 & 199 & 368 & 113323 \\
\hline S36 & 7533 & 25329 & 113085 & 111703 & 83496 & 7075 & 36267 & 143435 & 158594 & 164530 \\
\hline \multicolumn{11}{|l|}{ S37 } \\
\hline S38 & 781004 & 2449039 & 7057621 & 6484107 & 8803605 & 392565 & 1257654 & 6291256 & 8776348 & 13647421 \\
\hline S39 & 84551 & 319867 & 1143084 & 1263222 & 2605712 & 46329 & 188892 & 674905 & 673325 & 1125421 \\
\hline S40 & 55458 & 223985 & 835388 & 954268 & 1445485 & 49953 & 204113 & 1133317 & 1269870 & 1721865 \\
\hline \multicolumn{11}{|l|}{ S41 } \\
\hline \multicolumn{11}{|l|}{ Labour } \\
\hline \multicolumn{11}{|l|}{ Capital } \\
\hline \multicolumn{11}{|l|}{ ERH1 } \\
\hline \multicolumn{11}{|l|}{ ERH2 } \\
\hline \multicolumn{11}{|l|}{ ERH3 } \\
\hline \multicolumn{11}{|l|}{ ERH4 } \\
\hline \multicolumn{11}{|l|}{ ERH5 } \\
\hline \multicolumn{11}{|l|}{ EUH1 } \\
\hline \multicolumn{11}{|l|}{ EUH2 } \\
\hline \multicolumn{11}{|l|}{ EUH3 } \\
\hline \multicolumn{11}{|l|}{ EUH4 } \\
\hline \multicolumn{11}{|l|}{ EUH5 } \\
\hline \multicolumn{11}{|l|}{ Private } \\
\hline \multicolumn{11}{|l|}{ corporations } \\
\hline \multicolumn{11}{|l|}{ Public } \\
\hline \multicolumn{11}{|l|}{ Enterprises } \\
\hline Government & 36482 & 67422 & 3150664 & 501410 & 183574 & 0 & 0 & 2860696 & 2028029 & 915723 \\
\hline Indirect & 178926 & 545263 & 1621897 & 1351539 & 1496981 & 87606 & & & & \\
\hline taxes & & & & & & & 274399 & 1018390 & 1057557 & 1336482 \\
\hline Capital a/c & -440690 & 434894 & 2053573 & 7974004 & 28962560 & 63719 & 1805676 & 6426273 & 11238652 & 19062100 \\
\hline \multicolumn{11}{|l|}{$\begin{array}{l}\text { Rest of the } \\
\text { world }\end{array}$} \\
\hline Total & 3739651 & 13130353 & 42766647 & 39776390 & 63815445 & 2092624 & 8160625 & 32872295 & 37759078 & 50929910 \\
\hline
\end{tabular}

Note: Remove the columns RH1 to UH4 in Appendix Table 1. Add the three rows S30A to S30C to make it one row in Appendix Table 1. Then put Appendix Table 2 at the same place to obtain expenditure wise SAM.

\section{Copyright Disclaimer}

Copyright reserved by the author(s).

This article is an open-access article distributed under the terms and conditions of the Creative Commons Attribution license (http://creativecommons.org/licenses/by/3.0/). 